ISTIGHNA, Vol. 3, No 2, Juli 2020 P-ISSN 1979-2824 E-ISSN 2655-8459

Homepage: http://e-journal.stit-islamic-village.ac.id/index.php/istighna

Zen Amrullah, Akhmad Said

Orientasi Khodam Dalam Pendidikan Pesantren

\title{
ORIENTASI KHODAM DALAM PENDIDIKAN PESANTREN
}

\author{
Zen Amrullah \\ zenamrullah@gmail.com \\ STAI Ma'had Aly Al-Hikam Malang - Indonesia \\ Akhmad Said \\ seachsaidahmad@gmail.com \\ STAI Ma'had Aly Al-Hikam Malang - Indonesia
}

\begin{abstract}
The meaning of khodam in pesantren is another name for the help of the selfless Kiai, be it khadam bi al-tabarruk, bi al-Maqsud, which not everyone can become a Kiai khodam, they also help the Kiai in carrying out the duties of the pesantren and the housekeeping and economy for the sake of achieving a goal, namely getting blessings or benefits from a Kiai or teacher, although there are some khodam from outsiders who have never studied at the pesantren, khodam is an alternative for students who want to study at the pesantren but do not have sufficient costs to live it, so that by becoming a khodam, they can get an education with the help of their education costs by the Kiai. The view of the pesantren community regarding the existence of khodam basically, they are very helpful in the success of the educational process, with their existence, the students, ustad and even the general public find it easier to communicate with the caregiver or Kiai, Kiai sees khodam not as a marginalized santri, even, on the other hand, the khodam is already considered part of the pesantren's extended family so there is no difference between regular santri and santri who concurrently become this khodam.
\end{abstract}

\section{Keyword: Santri, Khodam}

\begin{abstract}
Abstrak: Makna khodam di pesantren pada hakekatnya merupakan nama lain kata pembantu kiai tanpa pamrih baik itu khadam bi al-tabarruk, bi al-Maqsud, yang tidak semua orang bisa menjadi khodahmnya kiai, mereka juga membantu kiai dalam melaksanakan tugas kepesantrenan serta kerumah tanggaan dan ekonomi demi mencapai suatu tujuan, yaitu mendapatkan barokah atau manfaat dari seorang kiai atau gurunya, walaupun ada sebagian khodam yang dari unsur orang luar yang tidak pernah nyantri di pesantren, khodam merupakan salah satu alternatif bagi para santri yang ingin menuntut ilmu di pesantren namun tidak mempunyai cukup biaya untuk menjalaninya, sehingga dengan menjadi khodam, maka mereka bisa mengenyam pendidikan dengan dibantu biaya pendidikannya oleh sang kiai. Pandangan masyarakat pesantren menyikapi eksistensi khodam pada dasarnya, mereka sangat membatu keberhasilan proses pendidikan, dengan keberadaan mereka, para santri, ustad dan bahkan masyarakat umum lebih mudah untuk melakukan komunikasi dengan sang pengasuh atau kiai,Kiai memandang khodam bukan sebagai santri yang di marjinalkan, bahkan sebaliknya, khodam
\end{abstract}

Peer reviewed under reponsibility of STIT ISLAMIC VILLAGE.

(C) 2018 STIT ISLAMIC VILLAGE, All right reserved, This is an open access article under 234 the CC BY SA license (https://creativecommons.org/licenses/by-sa/4.0/) 
ISTIGHNA, Vol. 3, No 2, Juli 2020 P-ISSN 1979-2824

Homepage: http://e-journal.stit-islamic-village.ac.id/index.php/istighna

Zen Amrullah, Akhmad Said

Orientasi Khodam Dalam Pendidikan Pesantren

sudah dianggap bagian dari keluarga besar pesantren sehingga tidak ada bedanya antara santri regular dengan santri yang merangkap menjadi khodam ini.

Kata Kunci: Khoddam, Pesantren

\section{A. PENDAHULUAN}

Dalam agama Islam, Pendidikan merupakan sesuatu hal yang sangat prestisius (berwibawa) dan realistis. Sebab, melalui ilmu (khususnya ilmu agama Islam) manusia akan lebih mengenal tuhan. Kehidupan manusia akan terasa hampa, jika manusia tidak memiliki ilmu agama. ${ }^{1}$ Secara teologis normatif derajat manusia dapat diukur berdasarkan ilmu yang dimiliki. Sebagaimana telah diisyaratkan dalam Al-Quran:

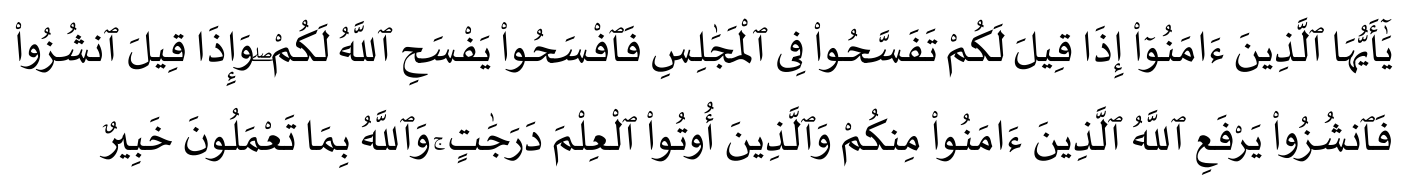

Artinya:

"Hai orang-orang beriman apabila kamu dikatakan kepadamu: "Berlapanglapanglah dalam majlis", Maka lapangkanlah niscaya Allah akan memberi kelapangan untukmu. Dan apabila dikatakan: "Berdirilah kamu", Maka berdirilah, niscaya Allah akan meninggikan orang-orang yang beriman di antaramu dan orang-orang yang diberi ilmu pengetahuan beberapa derajat. dan Allah Maha mengetahui apa yang kamu kerjakan.” (QS: Al-Mujadalah: 11)

Secara historis, pesantren merupakan tempat para pencari ilmu untuk memperoleh pendidikan agama. para pencari ilmu tersebut (santri) datang kepada seorang kyai yang memiliki kompetensi ilmu keagamaan kemudian belajar dan menekuni ilmu agama dengan mengkaji kitab-kitab kuning yang ada di Pesantren. Santri yang telah menyelesaikan pendidikannya dan telah dianggap memiliki kompetensi akan menyebarkan agama islam di lingkungan masyarakatnya masingmasing.

Mujamil Qomar menjelaskan bahwa terdapat tiga unsur utama dalam pendidikan pesantren, yaitu; Kiai, santri dan masjid. Bagi Qomar tiga unsur segitiga ini yang telah mewarnai pendidikan pesantren pada awal berdirinya. Unsur yang sederhana inilah yang mewarnai pengkajian islam. Pada perkembangannya,

${ }^{1}$ Rahmatullah, Rahmatullah, and Akhmad Said. "IMPLEMENTASI PENDIDIKAN KARAKTER ISLAM DI ERA MILENIAL PADA PONDOK PESANTREN MAHASISWA." TaLimuna: Jurnal Pendidikan Islam 8, no. 2 (2019): 37-52. 
ISTIGHNA, Vol. 3, No 2, Juli 2020 P-ISSN 1979-2824

Homepage: http://e-journal.stit-islamic-village.ac.id/index.php/istighna

Zen Amrullah, Akhmad Said

Orientasi Khodam Dalam Pendidikan Pesantren

pesantren melakukan pengembangan dari aspek fasilitas sebab tuntutan zaman dan bertambahnya santri yang belajar. ${ }^{2}$ Berkaitan dengan hal di atas Dhofir mengatakan ada lima unsur sebuah lembaga pendidikan Islam dapat disebut sebagai pesantren, yaitu; masjid, pondok, pengajaran kitab-kitab Islam klasik, santri dan Kiai. ${ }^{3}$ Unsurunsur ini saling berketerkaitan antara yang satu dengan yang lainnya hingga terbentuklah satu kesatuan yang disebut dengan pondok pesantren. ${ }^{4}$

Dalam tradisi pesantren dari aspek kemandirian, Cliford Gertz menyatakan bahwa keseharian santri memenuhi kebutuhannya dilakukan secaara mandiri, seperti memasak, mencuci pakaian, membersihkan asrama dan lain sebagainya. Pada sebagian pesantren, santri melakukan pekerjaan tersebut dilakukan kapan saja sesuai yang mereka inginkan. Begitu juga pekerjaan tersebut dilakukan secara kelompok atau sendiri. ${ }^{5}$ Bahka mereka membentuk sebuah organisasi yang mandiri dengan memilih pimpinan tanpa ada intervensi dair kiai.

Idealnya praktek kehidupan keseharian santri dilakukan secara mandiri untuk mempersiapkan pelaksanaan pembelakaran di pesantren, baik itu kesiapan spiritual maupun materi. Bekal spiritual adalah kesiapan mental untuk mengikuti berbagai aturan dan ketentuan kegiatan di pondok pesantren, seperti santri di wajibkan untuk mengikutin sholat berjamaah, belajar di kelas tiap pagi dan sore juga mengikuti pengajian-pengajian pada jam-jam yang di tentukan oleh pesantren. Sementara kesiapan materi merupakan kesiapan santri dalam bidang kebutuhan hidup seharaihari dipesantren, meliputi makan, kebutuhan mencuci mebeli kitab kuning daln lain sebaginya.

Kesiapan materi ini tak kalah pentingnya dalam menyongsong dan menjalani hidup dipesantren. Kenyataan yang kami temukan dalam kehidupan santri di pesantren adalah terkadang dari beberapa santri yang belajar di pesantren terdapat santri dari golongan yang kurang mampu (miskin secara ekonomi). Namun karena himmah (motivasi) yang besar untuk menuntut Ilmu maka mereka menempuh berbagai cara yang dipandang diridloi oleh Tuhan untuk tetap bisa menuntut Ilmu dan tinggal di pesantren.

${ }^{2}$ Mujamil Qomar, Pesantren dari Transformasi Metodologi Menuju Demokratisasi Institusi (Jakarta: Erlangga, 1996), 19.

${ }^{3}$ Zamakhsyari Dhofier, Tradisi Pesantren Studi Tentang Pandangan Hidup, (Jakarta: LP3ES, 1985) 44-45.

${ }^{4}$ A Rafiq, dkk, Pemberdayaan Pesantren Menuju Kemandirian dan Profesionalisme dengan Metode Daurah Kebudayaan, (Yogyakarta, LKiS Pelangi Aksara, 2005) , 3

${ }^{5}$ Clifford Geertz, Agama Jawa, Abangan, Santri, Priyai Dalam Kebudayaan Jawa, Terj, Aswab Mahasin dan Bur Rasuanto, (Depok: Komunitas Bambu, 2014), 267 
ISTIGHNA, Vol. 3, No 2, Juli 2020 P-ISSN 1979-2824

Homepage: http://e-journal.stit-islamic-village.ac.id/index.php/istighna

Zen Amrullah, Akhmad Said

Orientasi Khodam Dalam Pendidikan Pesantren

Secara sosiologis, status santri dapat dilihat dari dua katagori, yaitu santri mukim di asrama, dan santri yang mendi Khodam (pembatu kiai). Santri yang tidnggal di asrama adalah santri mayoritas yang berlatar belakang dari keluarga yang berkecukupan. Sementara santri Khodam adalah santri yang bertugas membantu urusan kiai dan keluarganya dalam segala urusan termasuk dalam bidang ekonomi kiai. Mereka bekerja di unit-unit usaha kiai atau gus.

Melihat kenyataan di atas, santri yang belajar di pesantren memiliki motovasi yang berbeda-beda, adakalanya santri yang khusus mencari ilmu agama secara muri dan ada santri yang mencari ilmu melalui berkah dari kiai. Sehingga tipe yang kedua ini memutuskan untuk mengabdikan diri kepada kiai sebagai Khodam. Pengabdian secara totalitas tanpa pamrih apapun kecuai keberkahan yang diharapkan oleh meraka.

Secara kasat mata menuntut ilmu dipesantren sambil menjadi Khodam bukanlah sesuatu yang mudah. Hampir bisa dikatakan tidak enak. Mengingat pekerjaan seorang Khodam sangat banyak. Secara ekonomis, pekerjaan menjadi khodam tidak mendapatkan bayaran papaun kecuali makan dari kiai. Apalagi diukur dari berstandar pada Upah Minimum Regional (UMR). Termasuk kenyamanan bekerja dan waktu bekerja sangat terbatas. Bahkan seorang Khodam kadang harus siaga 24 jam untuk selalu siap di panggil oleh kyai, yang tentu saja sebagaimana dalam doktri pesantren "semua santri termasuk santri yang menjadi Khodam harus ikhlas dalam melaksanakan semua pekerjaannya demi medapatkan keberkahan. ${ }^{6}$

Fenomena Khodam di atas, tampaknya Supandi dan Ni'mah telah memulai penelitian tentang Khodam dari berbagai aspeknya sekaligus di dua fokus yang berbeda meskipun masih di wilayah jawa timur. Dalam penelitian yang dilakukan Supandi pada dasarnya mencoba membaca fenomena Khodam dari aspek kiprahnya di pesantren mengungkap bahwa Khodam adalah salah satu cara alternative untuk mendapatkan pendidikan di Pesantren. Khodam secara fungsional bertugas sebagai mediator komunikasi antara masyarakat umum, guru pesantren atau santri. Khodam juga diterima sebagai keluarga besar oleh kiai layaknya seperti santri reguler. ${ }^{7}$

Sementara bagi Ni'mah menjelaskan bahwa terdapat relasi social antara kiai dan santri yang bersatus khodam dipesantren Al-Falah Ploso. Ni'mah menganalisa

6 Supandi, Supandi. "DINAMIKA SOSIO-KULTURAL KEAGAMAAN MASYARAKAT MADURA (Kiprah dan Eksistensi Khodam Dalam Pesantren di Madura)." AlUlum: Jurnal Penelitian dan Pemikiran Ke Islaman 4, no. 1 (2017): 26-42.

7 Supandi, Dinamika Sosio-Kultural Keagamaan Masyarakat Madura (Kiprah dan Eksistensi Khodam Dalam Pesantren di Madura). AL ULUM: Jurnal Penelitian dan Pemikiran Keislaman 4.1 (2017): 26-42. 
ISTIGHNA, Vol. 3, No 2, Juli 2020 P-ISSN 1979-2824

Homepage: http://e-journal.stit-islamic-village.ac.id/index.php/istighna

Zen Amrullah, Akhmad Said

Orientasi Khodam Dalam Pendidikan Pesantren

relasi di atas menggunakan teori pertukaran social (Social Exchange)). Ia memandang hubungan antara kiai dan khodam secara interpersonal.

\section{B. METODE PENELITIAN}

Pendekatan dalam penelitian ini adalah fenomenologi. Penelitian ini berusaha mengungkan fenomena dan kondisi Khodam (pembantu kiai) yang dialami dalam kehidupan seharai-hari. Peneliti berusaha hadir dalam penelitian ini selama penelitian berlangsung dengan berinteraksi dengan objek penelitian. Sementara dalam analisa penelitian ini, peneliti menggunakan berbagai disiplin ilmu sebagai upaya melihat fenomena dari bebagai sudut pandang (Multidisipliner). Psikologi, Pendidikan dan sosiologi. hal ini dilakukan karena peneliti berusaha meneliti dari aspek motivasi Khodam yang berdampak kepada berbagai aspek yang telah disebut di atas.

\section{HASIL PENELITIAN}

\section{Status Khodam sebagai sebuah Cita-cita Luhur}

Pada umumnya, seluruh kegiatan santri dipesantren telah terjadwal. Mulai bangun tidur hingga tidur kembali. Awalnya, santri masuk di pesantren Al-Falah Ploso diarahkan oleh santri senior untuk mengikuti pengajian di pondok sesuai dengan kemampuan dan kapasitas santri. Santri baru biasanya mengikuti pengajian kitab dasar dengan corak grammar Arab (Nahwu-Shorrof). Metode yang digunakan dalam pengajian kitab adalah sorogan dan bandongan. Sementara bahasa yang digunakan untuk memahami dan memaknai kitab tersebut adalah bahasa Jawa Kromo. Selain pengajian kitab nahwu dan shorof tersebut para santri juga mengaji kitab fiqh sebagai dasar pengetahuan ilmu agama.

Ada sebuah perbedaan yang menonjol antara santri yang tinggal di pesantren dan santri yang bersatus Khodam. Perbedaan tersebut terletak pada pengajian yang dilakukan oleh kedua kelompok tersebut. Biasanya khodam tidak bisa mengikuti pengajian yang dilaksanakan ole pesantren secara penuh seperti yang pengajian yang diikuti oleh santri lain. Perbedaan ini terjadi bukan disebabkan oleh perbedaan status. Melainkan kesibukan yang dimiliki oleh khodam. Meskipun khodam bisa mengikuti pengajian selain kegiatan wajib sebagai program pondok, khodam yang ingin mengikuti pengajian kitab bisa di lakukan di waktu-waktu senggang di luar kerja mereka. 
ISTIGHNA, Vol. 3, No 2, Juli 2020 P-ISSN 1979-2824

Homepage: http://e-journal.stit-islamic-village.ac.id/index.php/istighna

Zen Amrullah, Akhmad Said

Orientasi Khodam Dalam Pendidikan Pesantren

Sementara itu, pembelajaran kitab kuning di pesantren Al-Falah Ploso dilaksanakan, santri diberi kebebasan untuk memilih kitab untuk dikaji sesuai dengan motif dan minat santri. Dalam pembelajaran ini, santri mengkaji dengan santri yang lain, kemudian dirumuskan oleh santri senior. Pembelajaran ini diosebut dengan student learing aproachment. Keinginan santri dalam memilikih kitab sesuai dengan keinginannya tersebut merupakan keinginan yang didorong oleh motif intrinsik. ${ }^{8}$ sehingga materi yang dikehendaki bisa sesuai dengan yang diinginkan tanpa adanya unsur paksaan dari faktor lain. Di sisi lain, santri juga dapat memilih waktu yang tepat dalam melakukan pembelajaran tersebut. Hal demikian telah disampaikan oleh Ahmad Irfani :

"ya Alhamdulillah saya di kamar bisa belajar lebih focus dan konsentrasi daripada mereka yang menjadi khodam",

Gamabaran di atas berbeda dengan belajar para santri yang menjadi Khodam, dalam pengabdiannya santri Khodam tidak bisa belajar sesuai dengan yang diinginkan, seperti santri lain yang tinggal di asrama. Mereka (Khodam) harus mampu mengatur waktu antara belajar dengan bekerja baik di rumah Kiai, Gus, maupun di toko-toko milik Kiai dan Gus.

Khodam harus mampu menyeimbangkan antara pekerjaan dan belajar yang keduanya merupakan kewajiban. Sebab kondisi Khodam dituntut untuk fokus keudanya. Artinya tugas-tugas Khodam dalam menyelesaikan pekerjaan yang ditugaskan oleh kiai harus tepenuhi dan kewajiban belajar juga harus terpenuhi. Sehingga pengaturan waktu harus mampu ditangani oleh Khodam. Tugas-tugas sebagai Khodam, misalnya menjaga toko, masak dikantin atau bahkan mencuci pakaian keluaga kiai. Sementara tugas Khodam sebagai santri harus mampu menyelesaikan hafalan, memahami kitab kuning, bahkan menulis ulang mata pelajaran (Kitab Kuning).

Kamar husus disediakan oleh kiai bagi Khodam. Meskipun demikian, Khodam merasa kesulitan mengatur waktu dua kewajiban tersebut. Sebab selepas menyelesaika pekerjaannya, Khodam membutuhkan waktu untuk istirahat. Selain itu, santri lain berkunjung ke kamar Khodam untuk main. Faktor eksternal ini menjadikan khodam kesulitan menyelesaikan tugas-tugas belajarnya. Optimalisasi waktu yang tersisa terkadang tidak dapat dilaksanakan karna faktor eksternal tersebut. Salah satu Khodam menjelaskan bahwa ia merasa malu kepada teman-

${ }^{8}$ Hadi Wahyono, and Sholihul Anshori, Strategi Membangun Motivasi Ekstrinsik Santri Dalam Meningkatkan Kualitas Baca Kitab Kuning, (Studi Kasus di Pondok Putra Tebuireng Jombang)." al ta'dib 7.2 (2017): 155-169.

${ }^{9}$ Irfani, Wawancara, (Kediri: 2018) 
ISTIGHNA, Vol. 3, No 2, Juli 2020 P-ISSN 1979-2824

Homepage: http://e-journal.stit-islamic-village.ac.id/index.php/istighna

Zen Amrullah, Akhmad Said

Orientasi Khodam Dalam Pendidikan Pesantren

temanya yang berkunjung ke kamarnya, jika ia serius belajar. Sebab temantemnanya selalu membuli saat ia membaca kitab (mereviwe).

" owalah mas..., saya malu bila belajar di kamar ini..., soalnya banyak temen

yang pada main untuk makan-makan dan nyantai.., terkadang ketika saya mau buka buku saja ada yang bilang, wah rajin sekali kamu..."10

Pernyataan ini dapat difahami bahwa status Khodam sangat tidak diuntungkan dalam upaya mencari ilmu di pesantren. Meskipun demeikian mereka tetap optimis dalam menjalankan hidup dengan mengharap barokah dari kiai.

Tuntutan khodam harus mampu menguasai pelajaran, menghafal nadzoman, dan menulis ulang kitab kuning, mereka akan melaksanakan saat proses pembelajaran di kelas dilaksanakan. Artinya khodam tidak memiliki waktu untuk menyelesaikan hal di atas kecuali dilakukan di dalam kelas. Sebagai mana yang diutarakan sebagian Khodam.

Terus apa yang kau lakukan untuk bisa belajar dan menghafal al-fiyah ?

“ ya terpaksa untuk belajarnya saya hanya bisa ketika saat di kelas, karena kalau malam saya gak kuat melek belajar karena kecapaian". ${ }^{11}$

Dalam tradisi pesantren, terdapat doktrin kuat atas kondisi khodam tersebut. Salah satunya adalah khodam mengupayakan dirinya untuk dekat dengan guru. Doktrin kuat ini selalu disampaikan dengan mengutip salah satu pernyataan alZarnuji "Santri harus bisa dekat dengan gurunya". selain itu santri harus bisa mengagungkan gurunya sebagaimana dia mengagungkan kitab yang dipelajarinya. Argumentasi yang dibanguan adalah posisi guru dikaruniai ilmu Allah, maka selayaknya bagi guru mendapatkan penghargaan untuk dihormati. ${ }^{12}$ Oleh sebab itu, adabiyah senantiasa harus dijunjung tinggi oleh santri, baik selama belajar maupun sudah tamat. Dalam konteks ini Al-mawardi menjelaskan bahwa jika seorang pelajar yang ingin meraih ilmu secara sempurna, maka hendaknya merendahkan diri di depan guru dan mencari perhatiannya. ${ }^{13}$ Sebab dengan merendahkan diri akan menyebabkan guru selalu sabar dan perhatian dalam mendidiknya, sehingga santri mendapatkan perhatian khusus dan bisa menggali ilmu lebih banyak dari guru. Pendapat Al-Mawardi ini sejalan dengan hadis dibwah ini;

\footnotetext{
${ }^{10}$ Eko Febriyanto, Wawancara, (Kediri: 2018)

${ }^{11}$ Ib.id

${ }^{12}$ Al-Zarnujy, Ta'limul Muta'allim, (Pondok Pesantren Assalafi, Kediri, tt) hal.4

${ }^{13}$ Al-Imam al-Mawardi, Adabud Dunya wa Din, (al-Hidayah, Surabaya, tt), hal. 75
} 
ISTIGHNA, Vol. 3, No 2, Juli 2020 P-ISSN 1979-2824

Homepage: http://e-journal.stit-islamic-village.ac.id/index.php/istighna

Zen Amrullah, Akhmad Said

Orientasi Khodam Dalam Pendidikan Pesantren

Dalam hal keterangan di atas terdapat sebuah hadits yang menerangkan tentang kerendahan hati seorang murid terhadap gurunya, yang mana hadits itu adalah:

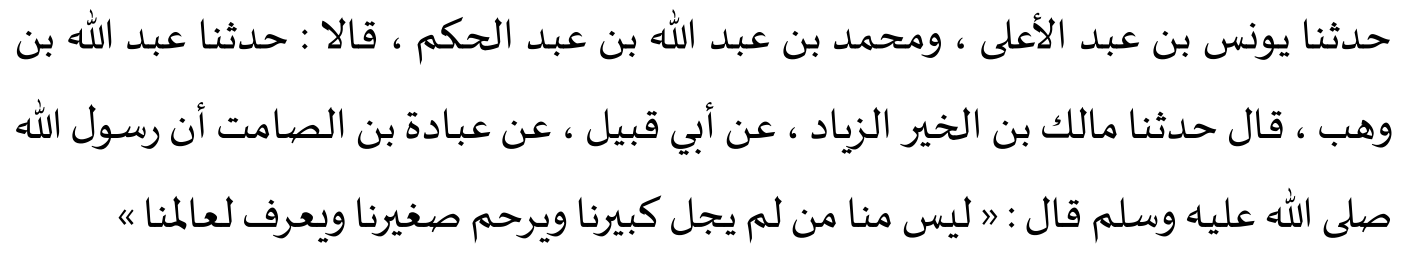

Artinya:

"Tidak termasuk golongan kami orang yang tidak memuliakan yang lebih tua dan menyayangi yang lebih muda serta yang tidak mengerti (hak) orang yang berilmu (agar diutamakan pandangannya). ${ }^{14}$

Penjelasan di atas adalah salah satu pijakan santri dalam memuliakan guru (Kyai), termasuk santri yang berstatus Khodam. Prinsip ini digunakan oleh Khodam dalam melayani kyai dengan penuh ikhlas dengan harapan mendapatkan barokah dan ilmu yang bermanfa'at. Selain itu, santri dalam menuntut ilmu harus memenuhi berbagai syarat antara lain; niat yang kuat, persiapan mental, cerdas, rakus terhadap pengetahuan, memiliki kesabaran yang tinggi, adanya petunjuk guru, memakan waktu yang lama ${ }^{15}$.

\section{Faktor Untuk Menjadi Abdi Dalem}

Penjelasan di atas dapat mempertegas bahwa santri yang belajar di pesantren harus mempunyai niat dan komitmen yang kuat dalam mencari ilmu agama. Namun demikian niat dan komitmen tampaknya tidak dapat dijadikan dasar utama bagi sebgaian santri, melainkan faktor lain juga menjadi dasar terselesainya pendidikan di pesantren, termasuk factor ekonomi. Di pesantren al-Falah Ploso Kediri, sebagian santri yang belajar tidak focus pada pencarian ilmu semata, melaikan bekerja sebagai khodam (pembantu). Menjadi khodam bagi sebagian santri bukan semata-mata hobi atau sekedar terhindar dari segala kegiatan yang diselenggarakan di pesantren. Mereka meliki berbaragam motivasi menjadi Khodam. Ada tiga (3) motivasi santri dalam belajar sambil kerja sebagai Khodam yang dapat dijelaskan sebagai berikut :

${ }^{14}$ Abu Ja'far Ahmad Al-Thahawi, Musykilah Al-Atsar, (Maktabah Syamilah: Mauqi' Jami’ Al-Hadist, tt), Juz III, hlm, 343.

15 Ahmad Mujib El-Shirazy dan Fahmi Arif El-Muniry, Landasan Etika Belajar Santri, (Pustaka Fajar, Jakarta Selatan, 2007), hal. 50 


\section{a. Pengalaman Kerja}

Jumlah Penduduk yang terus bertambah sementara sumber daya alam yang terbatas semisal jumlah sawah yang bisa ditanami oleh petani terus berkurang karena digunakan sebagai lahan pemukiman penduduk, memaksa penduduk Indonesia terutama yang tinggal di pulau jawa harus mempunyai tambahan skill yang laku di pasar kerja atau ketrampilan khusus yang potensial untuk bisa menghasilkan uang, dari fakta ini persaingan untuk bertahan hidup semakin keras.

Untuk hidup yang layak seorang santri tentu tidak cukup hanya mengandalkan pendapatan sekedar dari kemampuannya mengajar agama, imam masjid atau da'i keliling, karena doktrin agama dalam pesantren menjelaskan bahwa menyebarkan agama Islam atau dakwah tidak diperkenankan dengan tujuan mencari keuntungan materi.

Tidak setiap lulusan pesantren memiliki kompetensi sebagai Da'i atau ustadz yang laku berceramah di masjid-masjid atau dalam acara-acara seremonial kemasyarakatan. Di sisi lain, persaingan santri dengan lulusan perguruan tinggi di bidang keagamaan menjadi persoaalan tersendiri. Kondisi inilah yang menuntut santri untuk membangun kompetensi lain di bidang jasa atau skill yang mampu menopang kehidupan pasca lulus dari pesantren. Menyadari atas kondisi dan kompetensi yang dimilikinya, sebagian santri berusaha untuk menambah skill yang dimungkinkan dibutuhkan pasca lulus. Untuk memenuhi tambahan skill banyak hal yang dilakukan santri. Misalnya santri kursus bahasa inggris di kecamatan Pare. Biasanya santri yang melaksanakan kursus ini dilakukan saat liburan pesantren seperti bulan Maulid atau bulan Puasa.

Kondisi di atas tampaknya sudah disadari oleh beberapa pesantren. Tidak jarang pesantren memberikan sejumlah kursus atau diklat ketrampilan bagi para santrinya, atau bahkan menyediakan fasilitas latihan kerja bagi santri yang ingin memperolah pelatihan kerja. Dalam konteks pesantren Ploso tampaknya telah menyediakan terdapat beberapa unit usaha yang dapat dijadikan sebagai laboratorium usaha bagi santri. antara lain; Kantin, Pertokoan, Warnet, Peternakan dan Pertanian. Namun demikian seluruh unit usaha tersebut bukan milik pesantren melainkan milik pribadi Kiai atau Gus yang dikelola oleh santri. Sehingga pengelolaannya masih tergantung pada Kiai atau Gus.

Fakta bahwa pesantren Al falah (Ploso) terdapat berbagai unit usaha bisa dikatakan bahwa Pesantren sebagai fasilitator untuk tempat belajar kerja bagi para santri yang menginginkan penempaan diri dalam menyiapkan 
ISTIGHNA, Vol. 3, No 2, Juli 2020 P-ISSN 1979-2824

Homepage: http://e-journal.stit-islamic-village.ac.id/index.php/istighna

Zen Amrullah, Akhmad Said

Orientasi Khodam Dalam Pendidikan Pesantren

mencari rezeki dikemudian hari disamping tugas utama sebagai tempat menuntut ilmu agama. Dalam kasus Nurul Huda atau Iwan yang menjadi khodam karena keinginan memperoleh pengalaman kerja adalah timbul dari kesadaran bahwa mau tidak mau santri menyiapkan diri memasuki dunia kerja jika kelak telah lulus dari pesantren. Dengan demikian santri memiliki nilai tambah dihadapan masyarakat.

Selain itu, keberadaan pesantren harus memiliki orientasi balancing antara dunia dan akherat. Oleh sebab itu, maka pesantren berpotensi memberikan pendidikan keterampilan kepada santri untuk bisa mempersiapkan diri agar belajar bekerja demi memenuhi kebutuhan hidup dengan cara bekerja. Sehingga santri memiliki kompetensi ilmu agama dan tidak hanya bergantung kepada shodaqoh dari masyarakat. Tidak berlebihan jika Sa'id Aqiel Sirodj menyatakan bahwa keberadaan pesantren selain sebagai lembaga pendidikan dan keagamaan, pesantren juga sebagai lembaga pemberdayaan umat dan itu merupakan hal yang amat berarti bagi masa depan umat dan bangsa ${ }^{16}$.

Paparan di atas, secara teoritis dapat disebut sebagai metode pembelajaran experiential learning. Experiential Learning atau Pembelajaran Berbasis Pengalaman merupakan metode pembelajaran yang menekankan pada tantangan dan pengalaman yang disertai dengan refleksi hasil pembelajaran yang didapat dari pengalaman tersebut. Experiential Learning bukan hanya belajar dari sebuah pengalaman, melainkan juga sebuah pembelajaran yang menggunakan pengalaman sebagai media belajar. Pembelajaran experiential learning merupakan model pembelajaran yang memperhatikan atau menitikberatkan pada pengalaman yang akan dialami santri. santri terlibat langsung dalam proses belajar dan siswa mengkonstruksi sendiri pengalaman-pengalaman yang didapat sehingga menjadi suatu pengatahuan. santri akan mendapatkan pengalaman-pengalaman yang berbeda dari apa yang mereka telah pelajari, hal ini karena perbedaan dan keunikan dari masing-masing gaya belajar masing-masing santri.

Dalam kasus Nurul Huda dan Iwan, dapat dilihat bahwa mereka berdua bisa dilihat teori Experiential Learning. Yaitu keduanya mengekplorasi pengalamannya menjadi khodam (penjaga toko, kantin, asisten pribadi dan lain sebagainya) dengan terlibat langsung dalam pengelola sumber ekonomi Kiai dan Gus. Pada gilirannya mereka mampu mengkonstruksi sendiri pengalamannya menjadi sebuah pengetahuan.

16 Tim Dirjen Kelembagaan Agama Islam, Pola Pengembangan Pondok Pesantren, (Jakarta: Ditpekanpontren Ditjen Kelambagaan Agama Islam Departemen Agama, 200)3, hal. 91 
ISTIGHNA, Vol. 3, No 2, Juli 2020 P-ISSN 1979-2824

Homepage: http://e-journal.stit-islamic-village.ac.id/index.php/istighna

Zen Amrullah, Akhmad Said

Orientasi Khodam Dalam Pendidikan Pesantren

\section{b. Keberkahan Ilmu}

Secara terminologi, barokah adalah berkembang dan bertumbuh. Artinya bahwa barokah adalah anugerah allah dengan cara menjadikan segala sesuatu menjadi bertambah dan berkembang dengan sukses. ${ }^{17}$ Barokah dalam dunia pendidikan pesantren diyakini bahwa perolehan ilmu tidak hanya melalui proses belajar yang normative melainkan juga diimbangi dengan upaya mendapatkan keberkahan dari Kiai atau Gus.

Barokah bagi santri (terutama Khodam) adalah sesuatu yang istimewa. Mereka mempunyai dorongan kuat untuk menjadi Khodam. Dorongan kuat inilah yang menjadi alasan utama mereka memilih menjadi Khodam dengan argumentasi bahwa mencari ilmu selama dipesantren dapat menjadi berkah kelah setelah lulus dari pesantren. Salah satu bentuk memperoleh barokah adalah dengan mengabdikan diri kepada Kiai atau Gus selama menjadi santri.Selain itu, Khodam yang bekerja di unit usaha milik kyai dan Gus di pesantren Al-Falah selalu menjunjung tinggi keitimewaan kyai dan Gus. Artinya Khodam juga selalu mengagungkan dan meyakini akan kepiawaian ilmu yang dimiliki oleh kyai dan Gus.

Secara sosio-historis Imam Syafi'I sangat menghormat terhadap gurunya, yakni Imam Malik. Imam Syafi'I selalu membukakan lembaranlembaran kitab di hadapan Imam Malik, beliau melakukannya dengan sangat pelan, khawatir sang guru menjadi terganggu.

Kasus motif menjadi Khodam, Ahmad Hisyam misalnya, ia dalam pengabdiannya membantu pekerjaan di kantin juga berdasarkan keinginan ridho (rala) dari bu nyai $\mathrm{Hj}$. Laelatul Badriyah. Motif teologis ini muncul karena Hisyam berharap terjalin hubungan emosional antara Ibu Nyai (Istri Kiai) dengan Hisyam dan mendapat ridlo Allah.

Fenomena di atas menunjukkan bahwa Khodam dalam melakukian proses belajar merasa kurang mantab, apabila mereka belum menjadi Khodam, sekaligus dapat dikenal secara baik oleh gurunya. sehingga timbulah motivasi ekstrinsik dari dalam diri santri untuk menjadi Khodam tersebut. Meskipun dalam kenyataan mereka berpindah-pindah tempat (dari Kiai ke Kiai yang lain). Perpindahan tempa bagi mereka bukan sebuah persoalan. Hal terpenting bagi mereka adalah tercapainya tujuan menjadi Khodam.

\footnotetext{
${ }^{17}$ Muhammad Bin Ali Al-Syaukany, Fath Al-Qodir, (Maktabah Syamilah: TT), Juz IV,
} Hal, 454. 
ISTIGHNA, Vol. 3, No 2, Juli 2020 P-ISSN 1979-2824

Homepage: http://e-journal.stit-islamic-village.ac.id/index.php/istighna

Zen Amrullah, Akhmad Said

Orientasi Khodam Dalam Pendidikan Pesantren

Berbeda dengan Hisyam, Irfan mengabdikan diri kepada Kiai sebagai Khodam tampaknya lebih terpengaruh oleh lingkungan. Dalam hal ini, Irfan terpengaruh oleh teman sekamarnya. Secara psikologis, motif yang ada pada Irfan ini disebut sebagai motif sosiogenetis artinya bahwa motif ini dapat muncul dari interaksi sosial dengan orang lain atau hasil kebudayaan. ${ }^{18}$ Biasanya motif ini cukup banyak variandan dan berbeda-beda sesuai dengan berbedaan budaya.

Irafan yang bersatus sebagai Khodam ini diketahui bahwa ia telah terpengaruh oleh tetama-teman di lingkungannya yang juga berstatus khodam. Keinginan irfan memilih menjadi Khodam ini karena dorongan dari pergumulannya dengan teman-teman serta setelah mengetahui apa yang pernah di dawuhkan oleh Gus Miek. Sehingga dari motif ini merupakan tujuan yang mulia, bisa membantu guru dalam segala urusan.

\section{c. Biogenetif}

Persoalan keterbatasan ekonomi tidak hanya dialami oleh kelompok masyarakat secara umum, melainkan juga kelompok santri juga mengalami keterbatasan tersebut. Bagi sebagian santri menjadi Khodam adalah solusi dari keterbatasan ekonomi yang dialami sehari-hari. Sebab taraf ekonomi dari setiap orang tua santri memang berbeda. Sebagian wali santri ada yang kaya. Hal ini dibuktikan dengan kemampuan memberikan kiriman kepada putranya yang belajar di pesantren Al-Falah melebihi dari cukup. Sehingga kondisi keuangan santri tersebut bisa mencapai kebutuhan yang di perlukan untuk memenuhi segala kebutuhan selama melakukan proses pendidikan. Mulai dari perlengkapan ngaji, perlengkapan mandi, jajan, makan dan biaya hidup lainnya. Di sisi lain juga terdapat wali santri yang memiliki keterbatasan ekonomi. Sehingga uang saku yang diberikan kepada putranya hanya cukup memenuhi makan seadanya. Kondisi ekonomi wali santri yang lain cukup memperihatinkan. Meskipun kondisi ekonomi tidak mendukung, namun tidak mematahkan semangat dan tekad untuk mengirimkan anaknya ke pondok pesantren, agar anaknya memperoleh ilmu agama dan kelak bisa menjadi orang yang berguna bagi nusa dan bangsa.

Tipe wali santri yang ketiga ini, bukan berarti mengurangi semangat santri untuk tekun belajar. Untuk memenuhi kebutuhan sehari-hari santri dengan tipe wali satri yang serba kekurangan tersebut, mereka rela mengabdikan diri mereka kepada Kiai demi keberlangsungan belajar di pesantren. Ketercukupan ekonomi merupakan sebuah keniscayaan dalam

\footnotetext{
${ }^{18}$ Sarlito Wirawan Sarwono, Psikologi Sosial, (Jakarta, Balai Pustaka:2002) hal 46
} 
ISTIGHNA, Vol. 3, No 2, Juli 2020 P-ISSN 1979-2824

Homepage: http://e-journal.stit-islamic-village.ac.id/index.php/istighna

Zen Amrullah, Akhmad Said

Orientasi Khodam Dalam Pendidikan Pesantren

menjalankan pendidikan. Sebagaimana doktrin yang disampakan oleh alZarnuji dan diyakini oleh kalangan santri.

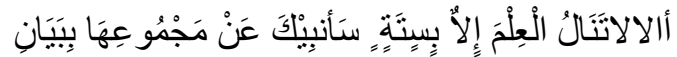

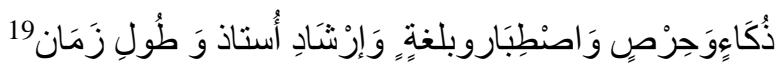

Secara ringkas penjelasan Al-Zarnuji di atas menegaskan bahwa seseorang tidak akan mendapatkan ilmu kecuali dengan enam perkara adalah cerdas, bijaksana, shabar, ada uang saku, guru yang pintar, dan masa yang relative lama untuk belajar.

Dalam konteks kebutuhan ekonomi, salah satu santri yang berada pada taraf ekonomi yang rendah adalah Kholiq. Ia mengatakan bahwa dorongan kuat untuk menjadi Khodam adalah tidak terpenuhinya kebutuhan sehari-hari selama berada di pesantren. Orang tuanya bukan tergolong orang yang berkecukupan pula. Dalam pandangan peneliti, keberadaan dorongan Kholiq memilih menjadi Khodam ini disebut dengan motif biogenetis. Motif ini adalah motif yang tumbuh dari sebuah kebutuhan organisme demi sebuah keberlanjutan hidup. Pada dasarnya motif ini berkembang sebagai sebuah respon terhadap kebutuhan jasmani masnusia. Selain itu, motif ini hadir bukan disebabkan oleh keterpengaruhan budaya atau lingkungan. Tidak heran jika Kholiq memilih menjadi Khodam. Karena ia memang harus memenuhi segala kebutuhannya demi tercapainya pendidikan di pesantren. ${ }^{20}$

Sebagai konsekwensi dari pilihannya, Kholiq harus rela mengorbankan waktu yang seharusnya dapat dimaksimalkan dalam pencapain pendidikannya. Sehingga ia harus merbah jam dan metede belajarnya. Baginya mengatur waktu harus sedapat mungkin dilakukan, misalnya pengaturan jam kerja dan memita teaman satu kelas memberikan penjelasan ulang atas pembelajaran yang tertinggal. Bahkan ia harus mebaca pelajaran (Kitab Kuning) diselala jaga kantin.

Hal yang sama juga terjadi pada Hawari. Ia mengatakan bahwa awalnya, ia mondok di pesantren Al-Falah ploso justru berawal dari pengabdian kepada Kiai. Ia menyadari sepenuhnya bahwa dalam pendidikan factor ekonomi sangat dibutuhkan. Dengan cara ia memilih menjadi Khodam, berharap agar kelak mendapatkan pendidikan dari pesantren. Keinginannya terpenuhi dengan mendapatkan izin dari Kiai. Hal ini dilakukan oleh Hawari

19 Al-Zarnuji, Ta"lìm Al-Muta"allim fì Tharīq al-Ta"allum, (Surabaya: Maktabah Shahabat Ilmu, tt), hal. 4

${ }^{20}$ Gerungan Dipl, Psikologi Sosial,(Bandung: Refika Aditama, 2010), Hal, 142 
ISTIGHNA, Vol. 3, No 2, Juli 2020 P-ISSN 1979-2824

Homepage: http://e-journal.stit-islamic-village.ac.id/index.php/istighna

Zen Amrullah, Akhmad Said

Orientasi Khodam Dalam Pendidikan Pesantren

sematamat untuk tidak membebani orang tuanya. Karena ia sadar bahwa orang tuanya memiliki keterbatasan ekonomi

Dalam urusan belajar, Hawari yang bertugas sebagai petani milik Ning Daris tidak mempermasalahkan tentang kekurangannya dalam belajar, karena pekerjaan yang dilakukan Hawari pada sore hari. Sehingga ia cukup ada waktu untuk belajar. Meskipun demikian, Hawari mengharap ada yang bias membimbingnya dalam memperoleh pendidikan selama di pesantren supaya bisa maksimal dari pelajaran. Membaca sendiri adalah cara yang tepat baginya agar tidak membebani orang lain.

\section{d. Feodalisme Pesantren}

Pesantren salaf merupakan akar dari ciri budaya pendidikan Islam yang ada di Indonesia. Dalam budaya pengajarannya sampai saat ini masih tetap terjaga dan lestari. adanya santri merupakan salah satu kompone lembaga pendidikan tersebut disebut dengan pesantren.

Tradisi dan budaya pesantren terutama di pesantren salaf adalah adabiyah (tatakrama). Santri sangat memuliakan Kiai dan keluarganya. Salah satu bentuk penghormatan santri kepada kiai dan keluarganya adalah rendah diri terhadap Kiai, Gus, dan guru kelas ketika bertemu. Sikap hormat, tadhim dan kepatuhan kepada Kiai adalah salah satu nilai pertama yang diutanamkan pada setiap santri ${ }^{21}$.

Berkaitan dengan status santri yang menjadi Khodam, kepatuhan terhadap kiai dan keluarganya adalah hal yang niscaya dan wajib dilakukan oleh mereka. Perintah Kiai yang harus di taati oleh santri karena ada pola hubungan status tinngi dan rendah. Pola hubungan ini dalam struktur masyarakat disebut dengan feudal. Pesantren sejak berdirinya masih menganut sistem sosial feudal. Pengkultusan terhadap sosok Kiai dan keluarganya masih melekat dikalangan masyarakat pesantren. Pengkultusan ini berimplikasi pada pola hubungan Kiai dan santri secara vertical. Pada dasarnya pengkultusan pada kiai dan keluarga bukan terjadi secara alamiyah, melainkan dipengaruhi oleh sebuah norma yang sumbernya dari penghormatan kepada guru. ${ }^{22}$

Sistem sosial yang feudal ini kemudian berdampak pada keterpaksaan santri untuk memilih menjadi Khodam. Padahal kehadiran mereka di

21. Marti Van Brunessen, Kitab Kuning, Pesantren Dan Tarekat : Tradisi-Tradisi Islam Di Indonesia, pengantar Abdur Rahaman wahid Mizan Bandung cet.3 rabiul awal 1420/Juli 1999

${ }^{22}$ Mohammad Takdir Ilahi,. Kiai: Figur Elite Pesantren, IBDA: Jurnal Kajian Islam dan Budaya 12.2 (2014): 137-148. 
ISTIGHNA, Vol. 3, No 2, Juli 2020 P-ISSN 1979-2824

Homepage: http://e-journal.stit-islamic-village.ac.id/index.php/istighna

Zen Amrullah, Akhmad Said

Orientasi Khodam Dalam Pendidikan Pesantren

pesantren bukan untuk bekerja, melainkan untuk mendalami ilmu agama. Persoaalan demikian ini terjadi pada beberapa santri yang antara lain di akui oleh Arifin. Dalam penuturannya, ia menjelaskan bahwa status Khodam yang melekat pada dirinya karena di perintah oleh Gus Zidni untuk bekerja di kantin makan kingwez Al-Falah dua. Artinya bahwa dorongan menjadi Khodam timbul dari perintah Guru. Bagi Arifinperintah guru adalah perintah tuhan yang harus dita'ati perintahnya.

Kondisi Arifin di atas berdampak pada kualitas belajarnya yang semakin menurun. Hal ini sebagai sebuah konsekwensi dari pekerjaannya sebagai Khodam. Padahal tujuan mondok di pesantren satu-satunya adalah belajar agama. Factor utama kualitas belajar Arimin menurun adalah lelah. Rasa lelah ini tidak dapat konsentrasi dalam belajar. Jika harus dipaksa belajarnya, tidak akan maksimal. Hanya tersisa kepasrahan dari Arifin yang bias diandalkan yaitu berharap ilmunya bermanfa'at.

Melihat kenyataan di atas tampaknya tradisi feodal di pesantren masih melekat. Sistem sosial feodal di Pesantren ini bukan berarti menadapat neliai negative. Namun sikap individual kiai sebagai pemangku utama dapat melahirkan keangkuhan spiritual yang melebar pada jarak antara Kiai dan santri bahkan dengan masyarakat tradisi feodal ini seolah menyetujui sikap kepemimpinan yang otoriter. Sehingga membuat santri dapat diperlakukan semau Kiai. Padahal posisi Kiai justeru memberikan Ta'dib dan Irsyad kepada santri, bukan menjadikan buruh dengan modal iming-iming barokah.

\section{KESIMPULAN}

Khodam adalah santri yang selain mencari ilmu, mereka juga membantu kiai dalam melaksanakan tugas kepesantrenan dan kerumah tanggaan demi mencapai suatu tujuan, yaitu mendapatkan barokah dari seorang kiai atau gurunya, walaupun ada sebagian khodam yang dari unsur orang luar yang tidak pernah nyatri di pesantren, Khodam merupakan salah satu alternative bagi para santri yang ingin menuntut ilmu di pesantren namun tidak mempunyai cukup biaya untuk menjalaninya, sehingga dengan menjadi khodam, maka mereka bisa mengenyam pendidikan dengan dibantu biaya pendidikannya oleh sang kiai atau pengasuh pondok pesantren dengan dibantunya biaya pendidikan memberi kemudahan khodam menempuh pendidikan untuk masa depannya.

Pada dasarnya, eksistensi khodam di pesantren sangat membatu keberhasilan proses pendidikan, signifikansinya masih belum sempat terukur, Hak Khodam adalah bagi yang masih dalam pendidikan, maka mereka di bayari oleh kiai, kemudian bagi yang tidak dalam masa pendidikan (sudah lulus) maka mereka 
ISTIGHNA, Vol. 3, No 2, Juli 2020 P-ISSN 1979-2824

Homepage: http://e-journal.stit-islamic-village.ac.id/index.php/istighna

Zen Amrullah, Akhmad Said

Orientasi Khodam Dalam Pendidikan Pesantren

mendapatkan tempat tinggal yang layak dari kiai, kemudian juga kebutuhan primer seperti makanan, pakaian dan lainnya juga menjadi tanggungan kiai.

\section{REFRENSI}

A Rafiq, dkk, Pemberdayaan Pesantren Menuju Kemandirian dan Profesionalisme dengan Metode

Abu Ja'far Ahmad Al-Thahawi, Musykilah Al-Atsar, (Maktabah Syamilah: Mauqi' Jami’ Al-Hadist, tt), Juz III.

Ahmad Mujib El-Shirazy dan Fahmi Arif El-Muniry, Landasan Etika Belajar Santri, (Pustaka Fajar, Jakarta Selatan, 2007.

Al-Imam al-Mawardi, Adabud Dunya wa Din, (al-Hidayah, Surabaya, tt).

Al-Zarnuji, Ta"lìm Al-Muta"allim fì Tharīq al-Ta"allum, (Surabaya: Maktabah Shahabat Ilmu, tt).

Al-Zarnujy, Ta'limul Muta'allim, (Pondok Pesantren Assalafi, Kediri, tt).

Clifford Geertz, Agama Jawa, Abangan, Santri, Priyai Dalam Kebudayaan Jawa, Terj, Aswab

Dalam Pesantren di Madura). AL ULUM: Jurnal Penelitian dan Pemikiran Keislaman 4.1 (2017).

Daurah Kebudayaan, (Yogyakarta, LKiS Pelangi Aksara, 2005).

Ditpekanpontren Ditjen Kelambagaan Agama Islam Departemen Agama, 2003).

Gerungan Dipl, Psikologi Sosial,(Bandung: Refika Aditama, 2010).

Hadi Wahyono, and Sholihul Anshori, Strategi Membangun Motivasi Ekstrinsik Santri Dalam Meningkatkan Kualitas Baca Kitab Kuning, (Studi Kasus di Pondok Putra Tebuireng Jombang)." al ta'dib 7.2 (2017).

Mahasin dan Bur Rasuanto, (Depok: Komunitas Bambu, 2014).

Marti Van Brunessen, Kitab Kuning, Pesantren Dan Tarekat : Tradisi-Tradisi Islam Di Indonesia,

Mohammad Takdir Ilahi,. Kiai: Figur Elite Pesantren, IBDA: Jurnal Kajian Islam dan Budaya 12.2 (2014).

Muhammad Bin Ali Al-Syaukany, Fath Al-Qodir, (Maktabah Syamilah: TT), Juz IV.

Mujamil Qomar, Pesantren dari Transformasi Metodologi Menuju Demokratisasi Institusi (Jakarta: Erlangga, 1996). 
ISTIGHNA, Vol. 3, No 2, Juli 2020 P-ISSN 1979-2824

Homepage: http://e-journal.stit-islamic-village.ac.id/index.php/istighna

Zen Amrullah, Akhmad Said Orientasi Khodam Dalam Pendidikan Pesantren

Pengantar Abdur Rahaman wahid Mizan Bandung cet.3 rabiul awal 1420/Juli 1999

Sarlito Wirawan Sarwono, Psikologi Sosial, (Jakarta, Balai Pustaka:2002).

Supandi, Dinamika Sosio-Kultural Keagamaan Masyarakat Madura (Kiprah dan Eksistensi Khodam

Tim Dirjen Kelembagaan Agama Islam, Pola Pengembangan Pondok Pesantren, (Jakarta:

Zamakhsyari Dhofier, Tradisi Pesantren Studi Tentang Pandangan Hidup, (Jakarta: LP3ES, 1985). 